\title{
How reflective is the academic essay?
}

The Issue

Engaging in critical academic discourse requires students to interrogate, and evaluate, their own thinking and reasoning. This process can be understood as reflection. However, while the literature increasingly suggests the diversification of assessment to improve validity (see, for example, Brown \& Glasner, 1999), the academic essay is the most common form of assessment in the Social Sciences (Brown et al, 1997). Performance in academic essay writing can be a significant source of data when judgemental decisions (such as course progression, honours classification and licence to practice) are made about students (Brown et al, 1997; Freeman \& Lewis, 1998). Given the preponderance of the essay in higher education and given the importance which is attributed to reflection, this study seeks to explore the extent to which reflection is evidenced in the academic essay. What is reported here is not about how reflective students themselves are, but about how students evidence reflection in a conventional academic essay. It is also noted that a fundamental assumption of the study is that writing can be a powerful mechanism for knowledge transformation and therefore for learning. While the academic literacies model (Lea \& Street, 2000) has much to offer in explicating student writing per se, the thrust of this study is a psychologically informed, small-scale analysis of the concept of reflection. Within such analysis no claim is made for the findings to have generalisability to other contexts.

\section{The Context}

Higher education is about enabling students to engage in academic discourse and develop intellectual autonomy (Barnett, 1990, 1992; Brockbank \& McGill, 1998; Miller, Imrie \& Cox, 1998). The purpose of equipping students with the conceptual tools required for independent thinking is to prepare them to participate in a future world which is, in large measure, unknown and unknowable (Bowden \& Marton, 1998). Since all that we have to prepare students for the future is our current knowledge, it is important that students can extrapolate from one situation to another and thus extend their experiences of the world (Newmann \& Archbald, 1992). 


\section{What is reflection?}

One recognised means through which intentional and autonomous learning can occur is through the process of reflection (Barnett, 1990; Boud, Keogh \& Walker, 1996; Cowan, 1998) and, in particular, through the process of reflective or transformative writing (Bereiter \& Scardamalia, 1987; Moon, 1999a). Distilling the theoretical perspectives of Dewey (1910) and Schön (1983, 1987), Boud et al (1996) describe reflection as a cognitive and/or affective response to some experience with the intention of coming to revised or new understanding(s) An essential feature of reflection is that while it can take place at an unconscious level, its use as a tool for learning depends on its being conscious (Boud et al, 1996; Marton \& Booth, 1997). As well as being purposeful, the mental processing of reflection is applied to relatively complex or unstructured ideas (King \& Kitchener, 1994). While there can be different purposes for reflection (Cowan, 1998; Moon, 1999a \& b), the intention to revise extant understandings and/or construct new understandings involves dealing with fuzzy ideas to reconcile ambiguity and inconsistency; to recognise the ways in which one's current knowledge and understanding are confused, incomplete or misconceived; and, generally, to make meaningful (for oneself) that which is disparate. Thus reflection is seen as being particularly useful for deep learning (Marton, Hounsell \& Entwistle, 1997), or for organising knowledge at the relational or extended abstract levels (Biggs \& Collis, 1982), because it can trigger activation of, and increase in, the skills of self-regulation (Ertmer \& Newby, 1996). Reflection is therefore, neither simplistically procedural nor routinely automatic. Rather it is intentional, effortful and may even be problematic (Bereiter \& Scardamalia, 1989).

\section{The role of writing in reflection}

The power of writing in the process of reflection is as a means for thinking (Nickerson, Perkins \& Smith, 1985). While writing can be a record of what one already knows (Bereiter \& Scardamalia, 1987), writing can also be the means through which one learns what one thinks about an issue (Kellog, 1994; Richardson, 1994). In trying to represent our thoughts to ourselves - and others - clearly, we have to work and rework our ideas. Writing can involve generating, integrating and evaluating ideas (Langer, 1986; Langer \& Applebee, 1987) 
thereby creating the possibility of precipitating intellectual change. However, according to Bereiter and Scardamalia $(1987,1989)$ writing can only be a mechanism for generative thinking if the writer holds a knowledge-transforming view of the writing task and has it as an intentional goal that as a result of engaging in the writing task, there is the possibility for change. Barksdale-Ladd et al (2001) found that, amongst academics, different foci in writing about a common issue led to differences in their practice of teaching. The task of writing reflectively encourages connections between declarative knowledge and practical experience (Yost et al, 2000) and further allows a response to the relationship between knowledge and experiences in professional practice (Eyler, 2001). Writing, then, can be powerful (though is not guaranteed to be so) because by engaging in writing, the potential to develop one's thinking, to revise or increase one's understanding or, simply, to learn is heightened (Kellog, 1994; McCrindle \& Christensen, 1995; Richardson, 1994; Watson, 2000).

\section{Where might this writing be found?}

Much of this reflective writing has typically been in learning journals (George \& Cowan, 1999; Moon, 1999b). A distinguishing feature of learning journals is that the learner is able to determine how the process of learning will be documented. Notwithstanding any guidance which the novice reflective writer may need in order to begin (Brockbank \& McGill, 1998; McCrindle \& Christensen, 1995), it is the freedom to experience, explore and evaluate his/her responses to the content-to-be-learned and to have these reflections as a legitimate and significant part of the writing task which enables learning to be enhanced (Watson, 2000). While most commonly associated with learning journals (Moon, 1999b; Morgan \& O'Reilly, 1999), it is perhaps limiting to conceive of reflective writing as their exclusive preserve.

Essays, for example, can require analysis, critique and argument (Hounsell, 1997; Miller et al, 1998; Morgan \& O'Reilly, 1999), and therefore have the potential to drive higher-order thinking (Resnick \& Resnick, 1993). And while essays can vary in what they require of students (Brown et al, 1997), the tasks of clarifying and extending one's mental representations of ideas, as is implied by Bereiter \& Scardamalia's (1987) knowledgetransforming model of writing, are not inconsistent with the demands of learning in the social 
sciences generally (Barnett, 1990) and the subtasks of essay writing in particular (Freeman \& Lewis, 1998). Given that the process of reflective writing has the potential to precipitate learning, as has been argued so far, and given that academic essays are popular (Brown et al, 1997) and pedagogically defensible (Hounsell, 1997; Miller et al, 1998; Morgan \& O'Reilly, 1999; Resnick \& Resnick, 1993), the purpose of this study was to explore the extent to which academic essays were reflective.

In attempting to characterise academic essays as reflective, there is the assumption that reflection can be described with differentiation of meaning. While fine-grained meaning for reflection is not particularly well developed, there is some substantiation for the view that reflection is not of a uniform quality (Allen \& Casbergue, 1997; Hatton \& Smith, 1995; King \& Kitchener, 1994; Perry, 1970), implying that distinctive forms of reflection can be identified. Hatton \& Smith (1995) are particularly clear in suggesting that different forms of reflection may represent a developmental hierarchy. Their framework for distinguishing between different forms of reflection may provide a focus for conceptualising reflection with greater differentiation of meaning than is commonly the case: a pedagogical development which would be important given the need for knowledge generation (Newmann \& Archbald, 1992). If such a framework can allow the development of critical abilities be documented in some detail, there could emerge a more differentiated appraisal of student cognition with respect to, say, the status of knowledge, what constitutes evidence and the ability to deal with contradiction.

\section{How the issue was investigated}

Materials Forty essay scripts from a pool of 90 were selected for analysis. The scripts, of 3500-4000 words, were in response to the question, 'To what extent does assessment enable the teacher to promote learning?' The criterion for determining which scripts were to be analysed was that of merit. In other words the scripts had all been marked as being of high quality because the assessors agreed that they demonstrated the following characteristics:

- an argued position on assessment 
- use of the literature to inform this position

- an analysis of the principles and purposes of assessment.

- a synthesis of professional development and practitioner experience.

While these characteristics are not themselves the object of study in this paper, they nevertheless read as consistent with argued, academic discourse (Entwistle, 1995; Norton, 1990; Smith et al, 1999) implying that the writers of such scripts could evidence a critical, questioning and reflective stance. By extension, essays which were at best satisfactory would in some way(s) fail to demonstrate the characteristics of high quality academic discourse. While, of course, it is conceded that even an unsatisfactory essay might evidence some reflection, the findings that there are variations in conceptualisation of an academic essay (Entwistle, 1995; Hounsell, 1997) and that students have difficulty in understanding what it means to engage in academic discourse (Chanock, 2000; Stefani \& Nicol, 1997) suggest that essays of high quality would be more likely to evidence reflection. In summary, the aim of the study was to determine the extent of reflection in a sample of student essays through content analysis of the responses.

The essays were written by teacher-education students in part completion of a one-year postgraduate course. The students had followed a programme of Professional Studies in which there were lectures, tutorials and readings (prescribed and recommended) on psychological perspectives of learning and teaching. Furthermore, a key feature of the delivery of the programme had been the constructive alignment of the curriculum of the programme with the assessment of students' learning (Biggs, 1999). By the time the students were constructing their essays, they had had considerable experience of trying to make links between theories of learning and practices of teaching and of making explicit the development of their own professional learning. 
Analysis The essays were analysed by two independent raters in terms of a framework (Table 1, below) developed by Maclellan (1999). This framework was influenced by Brockbank \& McGill (1998), Hatton \& Smith (1995), King \& Kitchener (1994) and Perry (1970) who collectively characterise the developing complexity through which the adult comes to describe and appreciate the world, and comprised:

- three elements of the reflective process: the conceptualisation, the implications and the veracity of the educational dilemma or issue (which in this study was the practice of assessment)

- four hierarchical levels of reflection: technical, descriptive, dialogical and critical reflection.

The framework required each essay to be read for what it had to say about the:

- conceptualisation of assessment,

- implications of assessment,

- veracity of assessment.

The elements of reflection did not represent a quantitative 'carve up' of the essay. Rather, they were qualitative and were conceived of as manageable but nevertheless comprehensive means of capturing varied and diverse content which was represented in text form. For each element it was then necessary to make a judgement as to whether the essay suggested:

- technical,

- descriptive,

- dialogical or

- critical reflection.

The quantification of phrases and sentences was not important, as the task was to discriminate between different levels of reflection. It was recognised that using a hierarchical categorization system for analysis could mean that different levels of reflection on each element would be evidenced in any one script. To manage the analysis in as straightforward a 
way as possible (albeit at the expense of richness of detail), the level of reflection assigned to each element was a global one based on what was predominant in the quality of each essay. Initial differences between the raters in the use of the framework were smoothed through rereadings of the essays and detailed discussion to reach shared meaning of the elements and levels.

Insert Table 1 about here, please.

\section{What was found out}

Insert Tables 2 and 3 about here, please.

Inspection of Tables 2 and 3 shows variation in the levels of reflection exhibited. Almost all of the students wrote at the descriptive (57 judgements) or dialogical (52 judgements) levels of reflection with few writing at the naive level of technical reflection (4 judgements) or at the most sophisticated level of critical reflection (7 judgements). Another initial observation of the data is that just over half of the essays evidenced internal variation in the levels of reflection. Furthermore in those cases there was a trend of being able to conceptualise assessment at a more sophisticated level than was sustained when discussing the veracity of assessment.

\section{The conceptualisation of the practice of assessment}

The conceptualisation of the practice of assessment suggested descriptive, dialogical and critical reflection. The following extracts exemplify the levels:

descriptive reflection (case 18)

Dockrell (1995) argues that teachers require a powerful understanding of assessment particularly the purposes and techniques of assessment. I agree with his view and it does concern me that my assessment technique may at present be lacking. Dockrell endorses my feelings when he says that teachers cannot afford to be amateur about assessment.

dialogical reflection (case 28)

Cohen (1996) defines the criteria by which the validity of an assessment can be judged. From this we can infer that a valid assessment is able to explain a pupil's performance in enough detail as to be of use to future planning. Summative assessment methods, carried out at the end of a period of study, to identify the standard of attainment achieved and which are frequently reported in terms of formal grades, show little evidence of such validity (Conner, 1999). Although summative assessment is what is lauded and promoted by politicians, its value to the teacher in promoting learning is less than clear. 
critical reflection (case 35)

In considering assessment there are a number of factors: type of assessment used, the fitness for purpose of the assessment, the conclusions drawn from the results and the way the information is used. Each of these factors is complex with there being competing evidence for the superiority of different perspectives. National Testing in Scotland is one such contentious issue. Its purposes are allegedly to confirm classroom-based assessment and to convey information on progress to parents. Given that it is the same teacher who marks the class work and the National Test, and given that the teacher is likely to use the one basis for marking both, it is difficult to see what exactly is being confirmed (perhaps the teacher's prejudices or ability?) and in what way(s) performance on the National Test provides any new information to parents. The purpose of National Tests is then unclear and their value questionable.

\section{The implications of the practice of assessment}

The implications of assessment suggested descriptive, dialogical and critical levels of

reflection. The following extracts exemplify the levels:

descriptive reflection (case 33)

Although each assessment has built in limitations and often does not maximize learning opportunities, the trick is to use multiple indicators of achievement in order to let learners demonstrate their potential on their own terms.

dialogical reflection (case 24 )

The teacher's assessment is only formative when teachers do something with the assessment results to promote learning. Effective questioning, observation, marking work and setting tests enable the teacher to gather information but if inappropriate action is taken as a result, then the assessment information ceases to be of any use in promoting learning (Stobbart \& Gipps, 1997). I realise now that in my own practice I have not been implementing effective assessment strategies. There is no point in returning marked work to children (as I have been doing) without also discussing the ways in which the work can be improved (a vital step that was omitted).

critical reflection (case 5)

The cognitive and social constructivist models imply that teachers need to assess individual children's existing knowledge before tackling new concepts. A particular manifestation of this is in the dominance given to criterion-referenced assessment. The time taken for diagnoses of individual cases means that the rest of the children in the class may be set a 'holding' task, which reduces the speed and standard of their learning. Further, the requirements for differentiated record-keeping places an enormous burden on teachers at the expense of other tasks in which the teacher might more profitably engage. Not only do the logistics of assessment differentially affect learning but so too might the design of the assessment task. A quiz, for example, might seem attractive to the children but it is likely that the quiz encourages rote learning (rather than meaningful understanding) and competition (which may be perceived as threatening or de-motivating). 


\section{The veracity of the practice}

The veracity of the practice of assessment suggested technical, descriptive, dialogical and

critical levels of reflection. The following extracts exemplify the levels:

technical reflection (case 16)

Formative assessment is beneficial at all stages of learning; at the start to gauge children's existing knowledge and to make progress towards learning outcomes. By implementing formative assessment the teacher is able to target and assist children who are struggling to develop the necessary skills (Pollard and Bourne, 1994)

descriptive reflection (case 30)

Having a degree in psychology, I naively believed that diagnostic assessment was used to identify problems. I now realize that diagnostic assessment can actually promote learning. It can help in the identification of gaps in knowledge and understanding, provide an indication of unevenness in development, diagnose weaknesses and so provide me with information to help prevent learning problems. By determining a child's ability level, the assessment allows me to place the child in an appropriate group that will foster learning. It is only through assessment that I can match activities to the pace and ability of each child.

dialogical reflection (case 1)

Teachers must be aware of the goals they stress. Research has shown that focusing on performance goals can have a detrimental effect on motivation and achievement (Dweck, 1986). It is far more effective to stress the importance of learning goals (Schunk, 1996). But teachers are often resistant to handing over responsibility to pupils, even though research has shown that self-assessment improves learning (Sebatane, 1998). Some teachers find it hard to move on from the traditional view of teaching and may require intensive staff development before feeling comfortable with newer practices (Fontana \& Fernandes, 1994).

critical reflection (case 8)

Whilst assessment does have a central place in the promotion of learning, it is not a panacea for all educational ills. Assessment per se will not provide solutions to issues such as attainment and the raising of educational standards. It is evident that many forms of assessment exist, and that at every juncture choices have to be made regarding its implementation. In order for assessment to be used effectively to promote learning, it is essential that teachers are aware of the type of learning they are trying to achieve. Without an understanding of the nuances of learning, it is unlikely that an appropriate form of assessment will be chosen. The multi-layered reality of assessment and learning means that it is imperative that teachers attempt to align the features of learning, assessment and feedback in such a way that students' existing understanding is developed.

\section{What the findings mean}

The purpose of the study was to explore how reflective academic essays were. In trying to characterise developmental levels of reflection the results will be discussed firstly in terms of the uniformity of reflection within essays and secondly in terms of the quality of reflection represented by technical, descriptive, dialogical and technical levels. 


\section{The Uniformity of Reflection}

Content analysis of the essays revealed that, while all 40 scripts had been graded as of high quality, 18 of the essays were judged to exhibit a uniform level of reflection but 22 were not. Where the level of reflection varied, students' conceptualisation of practice was at a more sophisticated level than their suggestions for how assessment practice might be improved. This may be a function of their prescribed reading where professional issues were described in considerable complexity. Many references to the reading were evident in the students' scripts. On the basis of their reading, students could internalise the detail and include it in their own conceptualisations of assessment. Further, that student's appreciation of the implications of assessment was almost always as sophisticated as their conceptualisations of assessment may be explained by the value that the students attributed to their field experiences. In their essays, students frequently and favourably invoked field experiences as instantiations of policies, principles and practices of assessment which had previously only been read about or talked about. However, understanding the veracity of assessment and of how this might be improved would be much more difficult, requiring students to think hard to develop some logical reasoning and discussion round the original conceptualisation. The difficulties which students experience in learning to think for themselves are extensively documented (Barnett, 1992; Brockbank \& McGill, 1998; Cowan, 1998).

\section{The Quality of Reflection}

Of the judgements made 4 were technical, 57 were descriptive, 52 were dialogical and 7 were critical. It is not surprising that so few students engaged in any technical reflection since the focus of such reasoning is that there are certain kinds of situations, and certain types of skills which can be brought to bear on such situations (as is exemplified in case 16) without any regard for the fact that skills are not independent of the situation(s) in which they are used and that, through use, they define and change the situation Schön (1987). In the context of this study technical reflection (a first and necessary level according to Hatton \& Smith, 1995) would be evidenced in an awareness by the students that while assessment practice falls short of what is perceived as ideal, such shortfall is attributed mostly to lack of experience; a lack 
which can be remedied with greater experience in the skills of assessment. But it was not the case in this study that students viewed assessment as unproblematic (since none of the cases conceptualised assessment at a technical level). Rather, they did view competent assessment as problematic but they didn't reason that if something is problematic, that of itself might be a reason to make change (Bowden \& Marton, 1998; Newmann \& Archbald, 1992). In other words the students were perceptually bound (Haskell, 2001) and so could make some sense of what they had read or experienced but could not extrapolate from this to a new, as yet-notexperienced situation. Such a conclusion is compatible with technical reflection since one of its defining features is its lack of regard for evidence (Nickerson, 1987) with the main criteria for evaluation being personal preference and prejudice (Hatton \& Smith, 1995). It is perhaps not surprising then that so few of the essays (although maybe it's surprising that any at all) evidenced technical reflection given that consideration of evidence is implied by the criteria (of constructing an argued position on assessment and use of the literature to inform this position) which had allegedly been met in the essays used for analysis in this study.

With the exception of 7 judgements of critical reflection, all the others were either descriptive or dialogical. The large number of descriptive reflection judgements is consistent with the findings of Hatton \& Smith (1995) who conclude that descriptive reflection is more easily mastered than the more demanding forms (of dialogical or critical reflection). In descriptive reflection the student is beginning to explain a phenomenon in terms of a range of reasons. There is awareness that the phenomenon is complex, largely through increasing recourse being made to the published output of experts. While the student at this stage of reflection can offer reasons for conclusions which have been reached or decisions which have been taken, varying or alternative positions about issues are seen as equally right or wrong (King \& Kitchener, 1994) and so the implications of one position or another are not considered, let alone worked out to their logical conclusions. As with technical reflection, the use of descriptive reflection does not include any explicit criteria (beyond those of personal whim) with which to evaluate different viewpoints. What this means here is that students were 
aware that the assessment of learning was important (because of their repeated statements that assessment is a necessary precursor to meaningful lesson planning); that assessment was problematic (because the literature reported this extensively) but that while certain changes to assessment practices were seen as desirable, these changes were viewed as logical corollaries to clearer understanding of what assessment is, rather than reasoned responses to what the evidence on assessment actually says or implies. Case 30 captures this idea neatly where the student demonstrates awareness of the existence of evidence, but the evidence itself is not considered or analysed. The dominance of 'knowledge collection' (Harvey \& Knight, 1996) which is implied by descriptive reflection is consistent with the student view that knowledge replication significantly defines learning in higher education (Eraut, 1994; Entwistle,1997; Kember, 1998; Prosser \& Trigwell, 1999). To this extent descriptive reflection is somewhat limited.

Fifty-two (52) of the judgements were at the more demanding level of dialogical reflection. Dialogical reflection is the deliberate engagement of the individual in both making the case for the logical strength of one point of view and also in constructing the objections to that point of view. It is the framing of an exchange (often couched in qualified and conditional language) between opposing points of view which characterises dialogical reflection. This exchange recognises the complexity of educational issues and the impossibility of solving educational problems through one frame of reference only, without necessarily coming to a logical conclusion as to the weight of the arguments presented. In the context of this study, students engaging in dialogical reflection recognized that the empirical support for assessment was open to interpretation (case 1) and that the conceptual underpinnings of assessment were variously significant (case 28) but although persuasive alternatives were offered in each case, the distinctions between, and the commonalities of, the claims of the argument were not made clear. Although dialogical reflection is demanding (Hatton \& Smith, 1995) because it is neither natural nor intuitive (Paul, 1987) it is arguably an important type of thinking. While we may be more than willing to believe that our own views are correct, moral and objective 
we need the experience of dialogical thinking to expose us to the likelihood that our assumptions are questionable and that our beliefs are inconsistent, egocentric and comfortably self-perpetuating (Paul, 1987). Because our understanding of the world is not 'given' but is indeed individually constructed by each one of us (Rogoff, 1999), our constructions of reality (our understandings) may be skewed or incompletely conceptualised. Through dialogical reflection we are disabused of the view that there are unambiguous and authoritative answers for the difficult questions and decisions we have to address. While dialogical reflection recognizes that knowledge is not certain (and to this extent represents an advance on descriptive reflection), the role of knowledge evaluation as a mechanism for creating new understandings (Kuhn, 1991; Haskell, 2001) is limited insofar as the critique of one point of view is merely implied by mounting a contrary point of view.

The seven (7) judgements at the level of critical reflection were the most sophisticated (Hatton \& Smith, 1995). However, the very concept of critical thinking is in itself problematic. Several significant voices (discussed by Kuhn, 1999) have offered definitions of critical thinking which are theoretically grounded insofar as there are concepts, principles, arguments and assumptions to support the definitions. But the definitions do not completely align with each other. None of them adequately grapples with the term, 'critical' so as to distinguish it from other types of thinking such as 'rational' or 'higher-order' or 'creative' or 'dogmatic' (Johnson,1992). Johnson's own characterisation of critical thinking (which tries to resolve the difficulties thrown up by previous definitions) is "the articulated judgement of an intellectual product arrived at on the basis of plus-minus considerations of the product in terms of appropriate standards (or criteria)" (page 49). In arriving at this definition Johnson (1992) is concerned to emphasise that:

- the etymology of 'critical' is to judge/appreciate/estimate the value of something;

- the focus of the critical thinker's scrutiny is thought (which may be manifest in beliefs, theories, hypotheses, arguments) rather than action; 
- the critical thinker's task is to apply the appropriate norms and standards to that intellectual product in order to judge its value;

- the critical thinker articulates his/her judgement so that the evaluation of the evidence is explicit.

Johnson's (1992) features of critical thinking do seem to be exemplified, at least to some extent, in cases 5,8 and 35 where there is sensitivity to a range of criteria, norms and value positions by which to evaluate the adequacy and veracity of the assessment of learning. In these cases there was a cognisance of the social, political and historical perspectives not only of assessment practices per se but also of the specific milieu within which assessment is conducted and so students' scripts suggested that they appreciated that there are ambiguities, inconsistencies and even contradictions in the educational provision of which they are a part. This is not to say that they accept the current limitations of assessment practices but they are aware that educational provision is in the context of a changing and permeable social world. The imperfect nature of what is in place and the need to strive for improvement is a feature of critical reflection.

\section{Conclusion}

Distilling the essence of the analysis and discussion of this study's data, it seems reasonable to summarise reflection as the process of co-ordinating extant understanding with new evidence. It is through such co-ordination that knowledge is acquired or constructed (King \& Kitchener, 1994; Kuhn, 1999). To the extent that there are developmental differences in the quality of reflection (on the role of assessment in the promotion of learning), the process of coordination was not uniformly evidenced in the sample of essays analysed. Technical Reflection suggests that evidence is not needed and that extant understandings will suffice indefinitely. Descriptive Reflection suggests that evidence exists but that it is not coordinated with understanding. Dialogical Reflection suggests that understanding and evidence are interdependent. Critical Reflection suggests in co-ordinating understanding and evidence, the evidence must be appraised for its veracity. It is Kuhn's (1999) contention 
(empirically substantiated) that the more control the individual has over this co-ordination process, the more effective the individual is in learning. This would suggest that critical reflection is a reasonable goal for all in higher education, although perhaps not achievable in the early undergraduate years (King \& Kitchener, 1994). While the sample of scripts analysed in this study had been graded 'merit' and were assumed to evidence a critical and reflective stance, such an assumption was erroneous with the data pointing to only a few scripts evidencing critical reflection. Notwithstanding the ambiguities in using the coding system (which were satisfactorily resolved within this study, but which would need clarification for future use), the findings suggest that assessment rubrics for academic essays in the Social Sciences could usefully articulate developmental levels of reflection so that not only were more reliable and transparent judgements made about the quality of the students' learning, but also that students themselves might gain more insight into, and control over, their own learning.

\section{References}

Allen, R. \& Casbergue, R. (1997) Evolution of novice through expert teachers' recall: implications for effective reflection on practice, Teaching and Teacher Education, 13, 7, pp. 741-55.

Barksdale-Ladd, M., Draper, M., King, J., Oropallo, K. \& Radencich, M. (2001) Four approaches to preservice teachers' involvement in the writing of case stories: a qualitative approach, Teaching and Teacher Education, 17, 4, pp. 417-31.

Barnett, R. (1990) The Idea of Higher Education (Buckingham, The Society for Research into Higher Education \&The Open University Press).

Barnett, R. (1992) Improving Higher Education. (Buckingham: The Society for Research into Higher Education \& The Open University Press).

Bereiter, C. \& Scardamalia, M. (1987) The Psychology of Written Composition. (NJ: Lawrence Erlbaum Associates).

Bereiter, C. \& Scardamalia, M. (1989) Intentional learning as a goal of instruction, in: L. Resnick (Ed) Knowing, Learning and Instruction (Hillsdale, NJ: Lawrence Erlbaum Associates).

Biggs, J. \& Collis, K (1982) Evaluating the Quality of Learning (London: Academic Press).

Biggs, J. (1999) Teaching for Quality Learning at University (Buckingham, The Society for Research into Higher Education \&The Open University Press). 
Boud, D., Keogh, R. \& Walker, D. (1996) Promoting reflection in learning: a model, in: R. Edwards, A. Hanson \& P. Raggatt (Eds) Boundaries of Adult Learning (London: Routledge in association with The Open University).

Bowden, J. \& Marton, F. (1998) The University of Learning. (London, Kogan Page).

Brockbank, A. \& McGill, I. (1998) Facilitating Reflective Learning in Higher Education. (Buckingham: The Society for Research into Higher Education \& The Open University Press).

Brown, G., Bull, J. \& Pendlebury, M. (1997) Assessing Student Learning in Higher Education (London: Routledge).

Brown, S. \& Glasner, A. (1999) Assessment Matters in Higher Education (Buckingham: The Society for Research into Higher Education \& The Open University Press).

Chanock, K. (2000) Comments on essays: do students understand what tutors write? Teaching in Higher Education, 5(1) pp. 95- 105.

Cowan, J. (1998) On Becoming an Innovative University Teacher (Buckingham: The Society for Research into Higher Education \& The Open University Press).

Dewey, J. (1910) How We Think. Boston: D. C. Heath \& Co. Publishers.

Entwistle, N. (1995) Frameworks for understanding as experienced in essay writing and in preparing for examinations, Educational Psychologist, 30(1), pp. 47-54.

Entwistle, N. (1997) Contrasting perspectives on learning, in: F. Marton, D. Hounsell \& N. Entwistle (Eds) The Experience of Learning (Edinburgh, Scottish Academic Press).

Eraut, M. (1994) Developing Professional Knowledge and Competence. (London: The Falmer Press).

Ertmer, P. \& Newby, T. (1996) The expert learner: strategic, self-regulated and reflective, Instructional Science, 24, pp. 1-24.

Eyler, J. (2001) Creating your reflection map, New Directions for Higher Education, 114, pp.35-43.

Freeman, R. \& Lewis, R. (1998) Planning and Implementing Assessment (London: Kogan Page).

George, J. \& Cowan, J.(1999) A Handbook of Techniques for Formative Evaluation (London: Kogan Page).

Harvey, L. \& Knight, P. (1996) Transforming Higher Education (Buckingham: The Society for Research into Higher Education \& The Open University Press).

Haskell, R. (2001) Transfer of Learning (London: Academic Press).

Hatton, N. \& Smith, D. (1995) Reflection in teacher education: towards definition and implementation, Teaching and Teacher Education, 11, 1, pp. 33-49.

Hounsell, D. (1997) Contrasting conceptions of essay-writing in: F. Marton, D.Hounsell \& N. Entwistle (Eds) The Experience of Learning (Edinburgh: Scottish Academic Press) 
Johnson, R (1992) The problem of defining critical thinking, in: S. Norris (Ed) The Generalizability of Critical Thinking (London: Teachers College Press).

Kellog, R. (1994) The Psychology of Writing, (Oxford: Oxford University Press).

Kember, D. (1998) Teaching beliefs and their impact on students' approach to learning, in: B. Dart \& G. Boulton-Lewis (Eds) Teaching and Learning in Higher Education (Melbourne, Australia: The Australian Council for Educational Research Ltd).

King, P. \& Kitchener, K. (1994) Developing Reflective Judgement (San Francisco: JosseyBass)

Kuhn, D. (1991) The Skills of Argument (Cambridge: Cambridge University Press).

Kuhn, D. (1999) A developmental model of critical thinking, Educational Researcher, 28, 2 pp. 16-25.

Langer, A. (1986) Learning through writing: study skills in the content area, Journal of Reading, 29(5) pp. 400-6.

Langer, J. \& Applebee, A. (1987) How Writing Shapes Thinking (Illinois: National Council of Teachers of English [NCTE] Research Report Number 22).

Lea, M. \& Street, B. (2000) Staff feedback: an academic literacies approach in: M. Lea \& B. Stierer (Eds) Student Writing in Higher Education (Buckingham: The Society for Research into Higher Education \& The Open University Press).

Maclellan, E. (1999) Reflective Commentaries: what do they say about learning? Educational Action Research, 7, 3 pp. 433-449.

McCrindle, A. \& Christensen, C, (1995) The impact of learning journals on metacognitive and cognitive processes and learning performance, Learning and Instruction, 5(2) pp. 167185.

Marton, F. \& Booth, S. (1997) Learning and Awareness (Mahwah, NJ: Lawrence Erlbaum Associates).

Marton, F., Hounsell, D. \& Entwistle, N. (1997) The Experience of Learning, (Edinburgh: Scottish Academic Press).

Miller, A., Imrie, B. \& Cox, K. (1998) Student Assessment in Higher Education (London: Kogan Page).

Moon, J. (1999a) Reflection in Learning and Professional Development (London: Kogan Page).

Moon, J. (1999b) Learning Journals (London: Kogan Page).

Morgan, C. \& O'Reilly, M. (1999) Assessing Open and Distance Learners (London: Kogan Page).

Nickerson, R., Perkins, D. \& Smith, E. (1985) The Teaching of Thinking (Hillsdale, New Jersey: Lawrence Erlbaum Associates). 
Nickerson, R. (1987) Why teach thinking? in: J.Baron \& R. Sternberg (Eds) Teaching Thinking Skills (New York: W.H.Freeman and Company)

Newmann, F. \& Archbald, D. (1992) The nature of authentic academic achievement, in: H. Berlak, F. Newmann, E. Adams, D. Archbald, T.Burgess, J. Raven, \& T. Romberg (Eds) Towards a New Science of Educational Testing and Assessment (New York, State University of New York Press).

Norton, L. (1990) Essay-writing: what really counts Higher Education, 20 pp 411-442.

Perry, W. (1970) Forms of Intellectual and Ethical Development in the College Years: A Scheme (New York: Holt, Rinehart \& Winston).

Paul, R. (1987) Dialogical thinking, in: J. Baron \& R. Sternberg (Eds) Teaching Thinking Skills (New York: W.H. Freeman \& Co).

Prosser \& Trigwell (1999) Understanding Learning and Teaching (Buckingham, The Society for Research into Higher Education \&The Open University Press).

Resnick, L. \& Resnick, D. (1993) Assessing the thinking curriculum: new tools for educational reform, in: B Gifford \& M. O'Connor (Eds) Changing Assessments: alternative views of aptitude, achievement and instruction (Massachusetts: Kluwer Academic Publishers).

Richardson, L. (1994) Writing. A method of enquiry, in: N. Denzil \& Y. Lincoln (Eds) Handbook of Qualitative Research (London: Sage).

Rogoff, B. (1999) Cognitive development through social interaction: Vygotsky and Piaget, in: P. Murphy (Ed) Learners, Learning and Assessment (London: Paul Chapman Publishing in association with The Open University).

Schön, D. (1983) The Reflective Practitioner (New York: Basic Books).

Schön, D. (1987) Educating the Reflective Practitioner (San Francisco: Josey-Bass).

Smith, D., Campbell, J. \& Brooker, R. (1999) The impact of students' approaches to essay writing on the quality of their essays, Assessment \& Evaluation in Higher Education, 24 (3) pp. 327-338.

Stefani, L. \& Nicol, D. (1997) From teacher to facilitator of collaborative enquiry, in: S. Armstrong, G. Thompson \& S. Brown (Eds) Facing up to Radical Change (London: Kogan Page).

Watson, S. (2000) Confessions from our reflective classroom, in: J. Smith \& K. Yancey (Eds) Self-Assessment and Development in Writing (Cresskill, N. J.: Hampton Press Inc).

Yost, D., Sentner, S. \& Forlenza-Bailey, A. (2000) An examination of the construct of critical reflection, Journal of Teacher Education, 51, pp.39-49. 
Table I The Framework

conceptualisation of assessment: the extent to which assessment is problematic; how this is manifest

\begin{tabular}{|l|l|}
\hline technical reflection & assessment is problematic for personal survival \\
\hline descriptive reflection & $\begin{array}{l}\text { assessment is problematic for specific (and possibly personal) } \\
\text { reasons or because the literature 'says' so }\end{array}$ \\
\hline dialogical reflection & $\begin{array}{l}\text { there is a range of evidence to suggest that assessment practice } \\
\text { is at least ambiguous if not problematic }\end{array}$ \\
\hline critical reflection & $\begin{array}{l}\text { assessment practice is multifaceted in terms of it complexity } \\
\text { and so has a range of consequences }\end{array}$ \\
\hline
\end{tabular}

the implications of assessment: the assumptions, values or beliefs embedded in assessment practice; whose interests are served by the perpetuation of the practice

\begin{tabular}{|l|l|}
\hline technical reflection & there is nothing questionable about assessment practice \\
\hline descriptive reflection & $\begin{array}{l}\text { there are some questionable or undesirable assessment } \\
\text { practices which are possible to correct- 'why don't others see } \\
\text { how sensible that would be?' }\end{array}$ \\
\hline dialogical reflection & $\begin{array}{l}\text { the underpinnings of any particular assessment practices are } \\
\text { not self evident and so what is good in one situation may not } \\
\text { be appropriate in another }\end{array}$ \\
\hline critical reflection & $\begin{array}{l}\text { there are many agendas operating and the difficulty lies in } \\
\text { determining whose is the most dominant }\end{array}$ \\
\hline
\end{tabular}

the veracity of assessment: in what ways assessment practice could be reframed

\begin{tabular}{|l|l|}
\hline technical reflection & $\begin{array}{l}\text { either make no change at all or make change because one is } \\
\text { told to do so }\end{array}$ \\
\hline descriptive reflection & $\begin{array}{l}\text { make change to improve the climate and/or learning in the } \\
\text { classroom }\end{array}$ \\
\hline dialogical reflection & make change on the basis of any well founded evidence \\
\hline critical reflection & $\begin{array}{l}\text { change is complex and is made on the basis of priority and } \\
\text { criteria }\end{array}$ \\
\hline
\end{tabular}


Table II: Levels of reflection for each commentary

\begin{tabular}{|c|c|c|c|}
\hline Case & $\begin{array}{c}\text { Conceptualisation of } \\
\text { Assessment }\end{array}$ & $\begin{array}{c}\text { Implications of } \\
\text { Assessment }\end{array}$ & $\begin{array}{l}\text { Veracity of } \\
\text { Assessment }\end{array}$ \\
\hline 01 & Dialogical & Dialogical & Dialogical \\
\hline 02 & Dialogical & Dialogical & Descriptive \\
\hline 03 & Dialogical & Dialogical & Dialogical \\
\hline 04 & Descriptive & Descriptive & Technical \\
\hline 05 & Critical & Critical & Dialogical \\
\hline 06 & Descriptive & Descriptive & Descriptive \\
\hline 07 & Descriptive & Descriptive & Descriptive \\
\hline 08 & Critical & Critical & Critical \\
\hline 09 & Descriptive & Descriptive & Descriptive \\
\hline 10 & Dialogical & Dialogical & Descriptive \\
\hline 11 & Dialogical & Dialogical & Descriptive \\
\hline 12 & Dialogical & Descriptive & Descriptive \\
\hline 13 & Dialogical & Dialogical & Descriptive \\
\hline 14 & Dialogical & Dialogical & Descriptive \\
\hline 15 & Descriptive & Descriptive & Descriptive \\
\hline 16 & Descriptive & Descriptive & Technical \\
\hline 17 & Dialogical & Descriptive & Descriptive \\
\hline 18 & Descriptive & Descriptive & Descriptive \\
\hline 19 & Descriptive & Descriptive & Descriptive \\
\hline 20 & Dialogical & Descriptive & Descriptive \\
\hline 21 & Dialogical & Dialogical & Descriptive \\
\hline 22 & Descriptive & Descriptive & Descriptive \\
\hline 23 & Dialogical & Dialogical & Dialogical \\
\hline 24 & Dialogical & Dialogical & Dialogical \\
\hline 25 & Dialogical & Dialogical & Descriptive \\
\hline 26 & Dialogical & Descriptive & Descriptive \\
\hline 27 & Dialogical & Dialogical & Dialogical \\
\hline 28 & Dialogical & Dialogical & Dialogical \\
\hline 29 & Dialogical & Descriptive & Descriptive \\
\hline 30 & Dialogical & Descriptive & Descriptive \\
\hline 31 & Dialogical & Dialogical & Dialogical \\
\hline 32 & Dialogical & Descriptive & Descriptive \\
\hline 33 & Descriptive & Descriptive & Technical \\
\hline 34 & Descriptive & Descriptive & Descriptive \\
\hline 35 & Critical & Critical & Dialogical \\
\hline 36 & Dialogical & Dialogical & Dialogical \\
\hline 37 & Dialogical & Descriptive & Descriptive \\
\hline 38 & Dialogical & Dialogical & Technical \\
\hline 39 & Dialogical & Dialogical & Descriptive \\
\hline 40 & Descriptive & Descriptive & Descriptive \\
\hline
\end{tabular}


Table III: Number of cases in each category at each level of reflection

\begin{tabular}{|c|c|c|c|c|c|}
\hline Case & $\begin{array}{c}\text { Technical } \\
\text { Reflection }\end{array}$ & $\begin{array}{c}\text { Descriptive } \\
\text { Reflection }\end{array}$ & $\begin{array}{c}\text { Dialogical } \\
\text { Reflection }\end{array}$ & $\begin{array}{c}\text { Critical } \\
\text { Reflection }\end{array}$ & TOTAL \\
\hline $\begin{array}{c}\text { Conceptualisation } \\
\text { of Assessment }\end{array}$ & 0 & 12 & 25 & 3 & 40 \\
\hline $\begin{array}{c}\text { Implications } \\
\text { of Assessment }\end{array}$ & 0 & 20 & 17 & 3 & 40 \\
\hline $\begin{array}{c}\text { Veracity } \\
\text { of Assessment }\end{array}$ & 4 & 25 & 10 & 1 & 40 \\
\hline TOTAL & 4 & 57 & 52 & 7 & 120 \\
\hline
\end{tabular}

Word Count: 6960 